DOI https://doi.org/10.32837/app.v0i65.314

УДК 321.7-028.79-021.146.4

\author{
O. В. КокорєВ \\ ORCID ID: https://orcid.org/0000-0001-7391-2498 \\ кандидат філософських наук, викладач \\ Коледжу зв'язку та інформатизаиії \\ Одеської національної академії зв'язку імені О. С. Попова
}

\title{
ВИЗНАЧЕННЯ ОСОБЛИВОСТЕЙ СТАНУ ЛІБЕРАЛЬНОЇ ДЕМОКРАТІЇ ЯК ПЕРЕДУМОВА ОЦІНКИ ІІЇ ЯКОСТІ В «МОЛОДИХ ДЕМОКРАТІЯХ» ЄС
}

Третя глобальна «хвиля» демократизації, розпочата в середині 1970-х років, набрала обертів у 1980-1990-х і досягла максимуму в 1993-1999 роках. Тоді велика кількість держав продемонструвала ліберально-демократичний поступ. У загальнопланетарному масштабі у 19782010 роках демократичний прогрес виражено домінував над демократичним регресом. Однак після цього поступального етапу подальший прогрес демократії сповільнився, а кількість держав із рецидивами авторитаризму незмінно зростає. За останню чверть століття саме нині кількість держав, які не відступають від впровадження демократичних стандартів і цінностей, є найменшою. Натомість тенденція автократизації посилюється. Тому хоч цінності ліберальної демократії й продовжують згуртовувати людей, зростає спільнота розчарованих тим, як вона працює; висхідною є недовіра до органів влади, інститутів демократії. Це своєю чергою зумовлює зниження якості демократії з причини радикалізації політики, посилення позицій популістських партій, наростання мови ненависті тощо.

Такі деструктивні процеси увиразнені, зокрема, в державах-учасницях $\in C$, а також у тих державах, які претендують на членство в цьому об'єднанні. Це при тому, що ЄС створений на основі цінностей демократії, свободи, верховенства закону, прав людини та ін. Тому всі дії як інституцій ЄС, так і держав-учасниць, іманентно мали б підпорядковуватися переліченим цінностям. Однак в останнє десятиліття політичні процеси, особливо в «молодих демократіях» $\mathrm{CC}$, засвідчують демократичний регрес. Вочевидь, на ці процеси вплинула загальнопланетарна тенденція відступу від демократії.

Згадані процеси увиразнилися в політологічному дискурсі останніх років: тут посилилися песимістичні настрої щодо перспектив неоліберальної демократії, тональність академічних розвідок є щораз тривожнішою. На це насамперед звертають увагу американські політологи. Так, Л. Даймонд означив нинішній період еволюції демократії як «демократичну рецесію» (Diamond, 2015). М. Платтнер аргументував, що демократія перебуває «в облозі» та зазнала ерозії (Plattner, 2017). Я. Мунк акцентував на недемократичному лібералізмі як реакції на популізм (Mounk, 2018). С. Левіцкі та Д. Зіблат висловили погляд на те, «як помирають демократії» (Levitsky, Ziblatt, 2018). Британський учений Д. Рансімен з'ясовує, «як закінчується демократія» (Runciman, 2018). Отже, дослідники останніми роками актуалізували вивчення питання кризи західної моделі ліберальної демократії, основних дефектів демократії, причин та наслідків деконсолідації демократії і под. «Молоді демократії» ЄС дають особливо широкий емпіричний матеріал для досліджень у цьому напрямі, відступаючи від засадничих принципів союзу.

Про те, що ліберальна демократія в СС переживає кризу, свідчать численні суперечності навколо демократичних принципів між державами Сходу та Заходу, Півночі та Півдня ЄС. Видається, що повертаються «хвороби» націоналізму та популізму, актуалізовані в 19201930-х роках. Попри те, що нині є доволі широке сприйняття демократії як оптимального політичного режиму, впевненість громадськості в цьому похитнулася за останні десятиліття під тиском неоавторитарного виклику, а громадянські та політичні права в усьому світі зазнають деструктивних утисків. Усе це спонукало ЄС неодноразово заявляти про готовність інвестувати в поглиблення стійкості неоліберальних демократій.

На кризу ліберальної демократії нині вказує підйом лівого та правого популізму, неліберальні урядові ініціативи, агресивна реакція окремих акторів політики на міграційну кризу 
(2015 р.), намагання влади звузити простір дії громадянського суспільства, утиски меншин (етнічних, сексуальних та ін.) тощо. Особливістю процесу демократичного відставання є його поступовий перебіг, тобто революційної стрімкості змін немає (Bermeo, 2016; Lust, Waldner, 2015).

Особливу загрозу ліберальній демократії становить піднесення правих і лівих популістів (Müller, 2016). Результати парламентських виборів у державах СС засвідчують стрімке зростання впливу популістських партій. Наприклад, у 2018 році в шістьох державах СС пройшли парламентські вибори й усюди зріс вплив популістських партій: Італія («Рух п'яти зірок», «Ліга Півночі»), Латвія (партія «Кому належить держава?», Нова консервативна партія), Словенія (Словенська демократична партія, партія «Ліві», Словенська національна партія), Угорщина («Фідес»), Швеція («Шведські демократи»). У 2019 році ця тенденція закріпилася: в Естонії пройшла до парламенту (а також увійшла до керівної коаліції та уряду) Консервативна народна партія Естонії; на виборах до ландтагів німецьких земель Тюрингія та Бранденбург зміцнила позиції правопопулістська партія «Альтернатива для Німеччини» тощо. Отже, на теренах ЄС висхідною $є$ підтримка популістських партій.

Звичайно ж, якість демократії в державах-учасницях $С С$ сильно різниться. В окремих із них ліберальна демократія переживає екзистенційну кризу, а в інших погіршення ії якості не має драматичного характеру. За останнє десятиліття Угорщина, Польща, Словаччина та Литва втратили статус ліберальних демократій, погіршивши характеристику національної демократії до рівня електоральної (за оцінками Інституту V-Dem) (Democracy Facing Global Challenges. V-Dem Annual Democracy, 2019). Нещодавно (2017 р.) Інститут V-Dem робив висновок про стійкість демократії в державах Європи (Lührmann et al., 2017; Mechkova et al., 2017), однак невдовзі ця оцінка похитнулася (Democracy for All? The V-Dem Annual Democracy Report 2018, 2018). Динаміка наростання дефектів демократії найбільш очевидна в субрегіонах Центральної Європи (Угорщина, Польща, Болгарія, Словаччина, Румунія) та Балкан (Сербія, Чорногорія); держави Балтії після приєднання до ЄС є радше прикладом стагнації, а не регресу в демократичних перетвореннях.

Держави, прийняті до ЄС у процесі останніх розширень, напередодні інтеграції демонстрували значний прогрес у ліберально-демократичних перетвореннях. Це засвідчувало, що ЄС справді наділений нормативною владою ${ }^{1}$ щодо держав-кандидатів. Однак після останніх розширень союзу щодо нових держав-учасниць послідовна та рішуча нормативна влада, як видається, не була збережена. Увага ЄС в останні роки до питань якості демократії не була належною. Це підтверджують дії окремих держав-учасниць, які не узгоджують свою національну політику з продемократичним курсом ЄС, відкрито нехтують цінностями правової держави та ліберальної демократії. Наявний спектр інструментів $Є С$ нині $є$ недостатнім, щоб ефективно запобігати погіршенню якості демократії в державах-учасницях. Хоч до держав-порушників може застосовуватися трирівнева процедура за ст. 7 Договору про ЄС (попередження, дисциплінарна процедура, санкціï), але кейси Угорщини та Польщі увиразнюють недосконалість такого механізму протидії ЄС проявам демократичного відступу. Це залишає відкритим питання про нові механізми контролю за дотриманням демократичних стандартів у державах-учасницях. Конструюються ідеї на взірець озвученої німецьким дослідником Я.-В. Мюллером про створення «Копенгагенської комісії» для захисту демократичних цінностей, які покладено в основу критеріїв вступу нових держав-учасниць до СС (Копенгагенські критерії) (Müller, 2015).

Тому в межах ЄC (як і в інших регіонах планети) наростає автократизація. Національні органи влади щоразу більше схильні віддавати перевагу прийняттю рішень на власний розсуд, без огляду на громадськість; посилюється тиск на опозицію, свободу слова; наростає політична корупція і под. Дедалі більший вплив на життєдіяльність держав отримує прошарок економічно могутніх. У діях окремих державних діячів, політичних партій, неформальних політичних об'єднань, особливо в «молодих демократіях» $С$, простежується неповага до конституцій і судової влади, радикалізм, мова ненависті. При цьому часто такі дії залишаються практично безкарними та завершуються озвученням «занепокоєності» інституцій ЄС конкретними деструктивними процесами.

\footnotetext{
${ }^{1}$ Мається на увазі здатність, змога ЄС контролювати дотримання певних (ліберально-демократичних) правил поведінки та за необхідності - наполягати на їх виконанні.
} 
Очевидно, що новітні цифрові технології, які мали б сприяти демократії та правовій державі, часто перетворюються на загрозу для них, є концентрованим увиразненням мову ненависті. Розвиток інформаційно-комунікаційних технологій пришвидшив тиск на ліберально-демократичні цінності: www-боти, ботруми, онлайн-тролі, DDoS- та DoS-атаки, поширення сфальшованої інформації тощо. 3' явилася велика кількість віртуальної «зброї» проти ліберально-демократичних цінностей. У «молодих демократіях» $Є С$ латентно функціонує ринок маніпуляції інформацією, найперше - в популярних соціальних мережах, на форумах, у коментарях новин тощо. На ринку мають попит послуги компаній, які формують інформаційне поле, розгортають інформаційні війни, використовуючи при цьому мову ненависті та інші деструктивні інструменти. Новітні методи впливу використовуються для формування «потрібної» громадської думки щодо соціально-чутливих тем, при цьому принижуються демократичні цінності, демонізуються іммігранти та біженці тощо.

Дискусійним залишається питання, коли був даний старт стрімкому наростанню дефектів демократії в посттоталітарних державах-учасницях ЄС - ще до початку глобальної фінансової кризи (2008р.), чи згодом - як ії результат? Ті дослідники, які підтримують першу гіпотезу (тобто до початку фінансової кризи), найчастіше причиною демократичного відступу називають низьку ефективність управлінської, політичної діяльності, високу корупцію в посттоталітарних державах (Pop-Eleches, 2010, с. 232). Початок відступу від цінностей ліберальної демократії, на думку прихильників цього підходу, стартував уже через два роки після «великого розширення» 2004 року (Sitter, Bakke, 2019). Його пов'язують з електоральною невдачею 2006 року угорської партії «Фідес»: увійшовши до парламенту, ця партія не змогла сформувати уряд, а тому В. Орбан озвучив думку про нелегітимність результатів цих виборів. Це поставило під сумнів мінімальні критерії демократичної консолідації, за якими усі основні політичні а́ктори приймають правила гри. На нашу думку, передумови для погіршення якості демократії в «молодих демократіях» Центральної та Східної Європи були закладені до глобальної фінансової кризи 2008 року, однак саме вона спрацювала як детонатор деконсолідації демократії.

Дослідники вказують на широкий спектр причин нинішнього демократичного відставання: вплив фінансово-економічних криз (Krastev, 2016), зміни в доходах на душу населення (Przeworski, 2005), відсутність демократичної традищії (Herman, 2016), піднесення популістських партій (Palonen, 2009), прийняття популістської риторики партіями як політичної стратегії (Pappas, 2014) та ін. Коли мова йде про «молоді демократії» СС, найперше, виділяються інституційні, політичні та економічні причини; також розглядаються етнічні, релігійні (Fish, Wittenberg, 2009) причини, показники розвитку громадянського суспільства (Greskovits, 2015) та ін.

Закцентуємо на трьох основних групах причин, які впливають на якість демократії держав-учасниць СС із Центральної та Східної Європи.

1. Інституиійні причини зосереджені найперше в площині національних виборчих систем, системи стримувань і противаг, стійкості інституцій (Batory, 2016; Buzogány, 2017; Enyedi, 2016; Palonen, 2009). Зокрема, Е. Рейнольдс (Reynolds, 2011) наголошує на важливості організації чіткої та зрозумілої виборчої процедури, що є неодмінним принципом демократії; дизайн виборчої системи має вирішальне значення для демократичної стабільності, оскільки він визначає рівень включеності партій та маргіналізованих груп. Е.Б. Капстайн та Н. Конверс (Kapstein, Converse, 2008) звертають увагу на важливість недопущення зловживань владою виконавчою гілкою. М.С. Фіш (Fish, 2001) аргументує, що в посткомуністичних державах система, яка уможливлює концентрацію влади виконавчою владою, є головним чинником демократичного відставання.

Дослідники акцентують: слабкість державних інститутів унеможливлює виконання ними тих функцій, які очікувані громадянами (Fukuyama, 2015, с. 14). Саме це і зробило, на думку I. Крастєва, молоді демократії Центральної та Східної Європи вразливими (Krastev, 2016, с. 36). Угорський політолог А. Аг переконаний: політичні інститути в цьому регіоні слабкі через недостатню народну підтримку, незначний досвід громадсько-політичного активізму, тобто в Центральній та Східній Свропі демократичні інститути впроваджувалися без такого соціокультурного контексту, який $є$ на Заході (Ágh, 2016, с. 277, 280). Своєю чергою це спричинило зниження авторитету демократії серед населення, а отже, активізацію й подальший прихід до 
влади неліберальних акторів. Саме тому наявність стійких, легітимних політичних інститутів розглядається як основний чинник недопущення зниження якості ліберальної демократії.

Безумовно, СС відіграв велику роль у розбудові демократичних інститутів держав, зацікавлених в євроінтеграції. Однак акцентування на інституційних змінах зумовило значно меншу увагу до змін на ціннісному рівні попри те, що політична культура громадян держав Центральної та Східної Європи мала (і має нині) серйозні відставання від ліберально-демократичного стандарту.

2. Політичні причини. Основною причиною в межах цієї групи, на нашу думку, є наростання правого та лівого популізму. Популісти прагнуть влади «в ім'я народу», а фундаментальні демократичні принципи та інститути розглядають як перешкоду своїм цілям.

Угорська політологиня А. Баторій аргументує: спільноти, які електорально підтримують популістські партії, не проходять «тест на демократію», бо лояльні до ідей, які ослаблюють ліберально-демократичні інститути (Batory, 2016, с. 284). На схожих позиціях перебувають Р.А. Губер і С.Г. Шимпф (Huber, Schimpf, 2016), які довели деструктивний вплив популістів, що увиразнюється в ігноруванні принципу стримувань і противаг, сприянні концентрації влади виконавчою гілкою, несхильності до компромісів у процесі прийняття політичних рішень тощо. Тобто згадані учені довели: популізм і ліберальна демократія несумісні; сильні популістські партії становлять потенційну загрозу неоліберальній демократії. Погоджуємося з фінською політологинею Е. Пелонен (Palonen, 2009), яка вважає, що популістські партії сприяють політичній поляризації та зменшують дискусію в політиці.

Дж. Доусон і Ш. Ханлі стверджують, що лібералізм не був уповні інтегрований у політико-правове життя держав Центральної та Східної Європи. Тому деструктивний спадок неліберальних режимів не є цілковито усунений і політичні еліти продовжують функціонувати під його впливом, а громадяни залишаються чутливими до популістських аргументів (Dawson, Hanley, 2016). На тілі наростання дефектів демократії в «молодих демократіях» СС слушно звучить висновок французького політолога Ж. Рупніка, що без справжньої зміни норм і політичної культури в «молодих демократіях» ліберальна демократія буде «порожнистою» (Rupnik, 2007, с. 22).

3. Економічні причини. Ця група причин демократичного відставання (як й інституційні) $є$ серед основних, на які звертають увагу дослідники. Американський політолог А. Пшеворскі (Przeworski, 2005) був серед перших, хто крізь призму економіки пояснив проблеми якості демократії, показавши узалежненість життєздатності демократії від розміру доходу на душу населення, рівня життя тощо. Дослідник переконаний, що економічні кризи дестабілізують демократичні системи. Зауважимо, вчені найперше звертають увагу на вплив на якість демократії глобальної фінансової кризи 2008 року.

I. Крастєв аргументує, що неспроможність ліберальної демократичної політики забезпечити економічне процвітання в умовах кризи може сприяти ще глибшій кризі демократії (Krastev, 2016, с. 38). А. Аг доводить: соціально-економічні проблеми та нерівності, що наростають унаслідок економічних криз у державах колишнього Східного блоку в період демократизації, відкрили політичне поле для неліберальних акторів політики, а громадськість відчула демократичну «втому» (Ágh, 2013). Загалом у політичній науці домінує думка, що економічне зростання, високі соціально-економічні показники сприяють збереженню та поступу ліберальної демократії.

Отже, вищесказане дає підстави вважати, що інституційні, політичні та економічні чинники є основою для пояснення демократичного відставання в державах-учасницях ЄС Центральної та Східної Європи. Однак ці три групи причин не є вичерпним поясненням деконсолідації демократії, позаяк кейси окремих держав увиразнюють національні особливості.

Наголосимо, що пандемія COVID-19 не лише відклала реалізацію ЄС низки завдань щодо покращення якості демократії, а й слугувала підставою окремим державам-учасницям форсовано звужувати демократичний громадянський простір, мотивуючи це потребою убезпечення від захворювання. Уже через кілька місяців після початку цієї пандемії очевидний їі руйнівний вплив не лише на життя та здоров'я громадян, економіку та соціальну сферу, а й на демократію, права людини тощо. Пандемія стала підставою для не завжди виправданих 
звужень демократичного громадянського простору, нехтування верховенством права, обмеження свободи вираження поглядів тощо. Свропейські демократії стикнулися з обмеженнями свободи зборів, пересування, посиленням виконавчої влади тощо. COVID-19 став новим чинником зниження довіри населення до влади з огляду на вимушене звуження прав людини та громадянина, скорочення робочих місць, різке поглиблення соціально-економічних проблем тощо.

Отже, окремі уряди країн ЄС у 2020 р. розширили повноваження більше, ніж цього вимагає надзвичайна ситуація з пандемією COVID-19, і використали це для посилення тиску на демократичні інститути. Наприклад, В. Орбан домігся надання йому парламентом Угорщини (30.03.2020 р.) надзвичайних повноважень, наприклад, видавати декрети, які мають силу закону. Також уряди окремих держав СС використали ситуацію з поширенням коронавірусу для радикалізації міграційного питання. Наприклад, Міністерством внутрішніх справ Естонії було ініційовано внесення нормативно-правових змін, які дозволяють уряду в односторонньому порядку відкликати візи на довгострокове перебування, дозволи на проживання та роботу для громадян третіх держав у разі втрати ними роботи на естонському ринку праці в умовах пандемії.

Антипандемічні заходи навесні 2020 р. зумовили випадки обмеження діяльності правозахисників, журналістів, організацій громадянського суспільства. Окремі уряди почали прицільно використовувати ситуацію боротьби з пандемією для тестування нових методів масового спостереження за населенням, що суперечить правам та свободам людини. I хоч тут радше йдеться про неоавторитарні держави, це актуально й щодо окремих держав-учасниць ЄС. Загалом події першої половини 2020 р. зумовили актуалізацію в політологічному дискурсі питання: чи «переживе» ліберальна демократія пандемію COVID-19?

Очевидно, що на тлі пандемії COVID-19 якість демократії знизиться з огляду на: перенесення в багатьох державах чергових виборів; тимчасове зупинення або винесення в онлайн роботи парламентів; розгляд судами лише невідкладних справ; обмеження свободи зібрань; роботу більшості журналістів вдома, у результаті чого унеможливлений належний збір інформації і т.д. Затяжні карантинні заходи посилили загрози обмеженню прав і свобод громадян, загрожують верховенству закону, позбавляють впливу опозиційних а́кторів. Фактично ця пандемія $є$ тестом для ліберальної демократії держав ЄС (і планети загалом) на стресостійкість. Очевидно, в кризові періоди соціальна єдність, солідарність, соціальна відповідальність $\epsilon$ важливішими, ніж будь-коли, однак попри зміщення пріоритетів, свобода вираження поглядів і демократичний нагляд за владою не мають бути ослаблені.

Видається, що не зміцнення демократичних цінностей, а проблеми безпеки, протидія кліматичним змінам, а віднедавна - боротьба з пандемією COVID-19 нині виступають пріоритетами СС. Завдання «порятунку» економіки, а не демократії, набуло особливої значущості для $С$, адже світова економіка увійшла в рецесію $\mathrm{i}$, за прогнозами МВФ, у неї є перспектива найгірших (після Великої економічної депресії 1930-х років) часів. Однак за наявних дефектів демократії та динамічного погіршення ії якості, політика ЄС щодо зміцнення цінності ліберальної демократії, запобігання руйнування ऑї основ, на нашу думку, має вийти на передній план. Відсутність цілісної політики зміцнення ліберальної демократії є однією із серйозних загроз перспективі функціонування $\mathrm{CC.}$

За нашими оцінками, нинішні дії СС щодо покращення якості демократії, запобігання дедемократизації є лише фрагментарною колекцією політичних відповідей на певні виклики. Нині не вироблений цілісний узгоджений план дій СС щодо зміцнення демократії й справді дієвого запобігання наростанню ії дефектів. ЄС радше концентрується на проєктах підтримки демократії на національному рівні, однак, вважаємо, потребує якнайшвидшого осмислення макрорівнева стратегія демократичного прогресу СС. Для зміцнення демократії у країнах Центральної та Східної Свропи і загалом для перспективи ЄС це дуже значимо.

\section{Лimepamypa:}

Ágh A. The triple crisis in Hungary: The "Backsliding" of Hungarian Democracy after Twenty Years. Romanian Journal of Political Science. 2013. Vol. 13. № 1. P. 25-51.

Ágh A. The Decline of Democracy in East-Central Europe: Hungary as the Worst-Case Scenario. Problems of Post-Communism. 2016. Vol. 63. № 5-6. P. 277-287. 
Batory A. Populists in government? Hungary's "system of national cooperation". Democratization. 2016. Vol. 23. № 2. P. 283-303.

Bermeo N. On Democratic Backsliding. Journal of Democracy. 2016. Vol. 27. № 1. P. 5-19.

Buzogány A. Illiberal democracy in Hungary: authoritarian diffusion or domestic causation? Democratization. 2017. Vol. 24. № 7. P. 1307-1325.

Dawson J., Hanley S. The Fading Mirage of the «Liberal Consensus». Journal of Democracy. 2016. Vol. 27. № 1. P. 20-34.

Democracy Facing Global Challenges. V-Dem Annual Democracy. Gothenburg : University of Gothenburg, 2019. $76 \mathrm{p}$.

Democracy for All? The V-Dem Annual Democracy Report 2018. Gothenburg : Varieties of Democracy Institute, University of Gothenburg, 2018. 96 p.

Diamond L. Facing up to the democratic recession. Journal of Democracy. 2015. Vol. 26(1). P. 141-155.

Enyedi Z. Populist Polarization and Party System Institutionalization: The Role of Party Politics in DeDemocratization. Problems of Post-Communism. 2016. Vol. 63. № 4. P. 210-220.

Fish M.S. The Dynamics of Democratic Erosion. Postcommunism and the theory of democracy / R.D. Anderson et.al. Chichester; Princeton : Princeton University Press, 2001. 216 p.

Fish M.S. Wittenberg J. Failed democratization. Democratization. New York : Oxford University Press, 2009. P. 260-265.

Fukuyama F. Why Is Democracy Performing So Poorly? Democracy in decline? / L.J. Diamond, M.F. Plattner (eds.). Baltimore : Johns Hopkins University Press, 2015.

Greskovits B. The Hollowing and Backsliding of Democracy in East Central Europe. Global Policy. 2015. Vol. 6. № 1. P. 28-37.

Herman L. Re-evaluating the post-communist success story: party elite loyalty, citizen mobilization and the erosion of Hungarian democracy. European Political Science Review. 2016. Vol. 8. № 2. P. 251-284.

Huber R.A., Schimpf C.H. Friend or Foe? Testing the Influence of Populism on Democratic Quality in Latin America. Political Studies. 2016. Vol. 64. № 4. P. 872-889.

Kapstein E.B., Converse N. The fate of young democracies. Cambridge : Cambridge University Press, 2008. $188 \mathrm{p}$.

Krastev I. Liberalism's Failure to Deliver. Journal of Democracy. 2016. Vol. 27. № 1. P. 35-38.

Levitsky S., Ziblatt D. How Democracies Die. New York: Crown, 2018. 312 p.

Lührmann A. et al. Democracy at Dusk? V-Dem Annual Report 2017. Gothenburg: Varieties of Democracy Institute, University of Gothenburg, 2017. 60 p.

Lust E., Waldner D. Theories of Democratic Change - Phase I: Theories of Democratic Backsliding. USAID Research and Innovation Grants Working Papers Series, 2015. 123 p.

Mechkova V., Lührmann A., Lindberg S. I. How Much Backsliding? Journal of Democracy. 2017. Vol. 28. № 4. P. 162-169.

Mounk Y. The people vs. democracy. Why our freedom is in danger and how to save it. Harvard : U Press, 2018. $400 \mathrm{p}$.

Müller J.-W. Should the EU Protect Democracy and the Rule of Law inside Member States. European Law Journal. 2015. Vol. 21. № 2. P. 141-160.

Müller J.-W. What is populism? Philadelphia : University of Pennsylvania Press, 2016. 136 p.

Palonen E. Political polarisation and populism in contemporary Hungary. Parliamentary Affairs. 2009. Vol. 62. № 2. P. 318-334.

Pappas T. Populist Democracies: Post-Authoritarian Greece and Post-Communist Hungary. Government and Opposition. 2014. Vol. 49. № 1. P 1-23.

Plattner M.F. Liberal democracy's fading allure. Journal of Democracy. 2017. Vol. 28. № 4. P. 5-14.

Pop-Eleches G. Throwing out the bums. Protest voting and unorthodox parties after communism. World Politics. 2010. Vol. 62. № 2. P. 221-260.

Przeworski A. Democracy as an Equilibrium. Public Choice. 2005. Vol. 123. № 3/4. P. 253-273.

Reynolds A. Designing democracy in a dangerous world. Oxford : Oxford University Press, 2011. 218 p.

Runciman D. How democracy ends. London : Profile Books, 2018. 256 p.

Rupnik J. From Democracy Fatigue to Populist Backlash. Journal of Democracy. 2007. Vol. 18. № 4. P. 17-25.

Sitter N., Bakke E. Democratic Backsliding in the European Union. Oxford Research Encyclopedia of Politics, 2019. 


\section{References}

Ágh, A. (2013). The triple crisis in Hungary: The "Backsliding" of Hungarian Democracy after Twenty Years. Romanian Journal of Political Science, № 13(1). P. 25-51. [in English]

Ágh, A. (2016). The Decline of Democracy in East-Central Europe: Hungary as the Worst-Case Scenario. Problems of Post-Communism. № 63(5-6), P. 277-287. [in English]

Batory, A. (2016). Populists in government? Hungary's "system of national cooperation". Democratization. № 23(2). P. 283-303. [in English]

Bermeo, N. (2016). On Democratic Backsliding. Journal of Democracy, 27(1). P. 5-19. [in English]

Buzogány, A. (2017). Illiberal democracy in Hungary: authoritarian diffusion or domestic causation? Democratization. № 24 (7). P. 1307-1325. [in English]

Dawson, J., Hanley, S. (2016). The Fading Mirage of the «Liberal Consensus». Journal of Democracy, № 27(1), P. 20-34. [in English]

Democracy Facing Global Challenges. V-Dem Annual Democracy (2019). Gothenburg: University of Gothenburg. 76 p. [in English]

Democracy for All? The V-Dem Annual Democracy Report 2018 (2018). Gothenburg: Varieties of Democracy Institute, University of Gothenburg. 96 p. [in English]

Diamond, L. (2015). Facing up to the democratic recession. Journal of Democracy, № 26(1), P. 141-155. [in English] Enyedi, Z. (2016). Populist Polarization and Party System Institutionalization: The Role of Party Politics in DeDemocratization. Problems of Post-Communism, № 63(4), P. 210-220. [in English]

Fish, M.S. (2001). The Dynamics of Democratic Erosion. In: Anderson, R.D. et.al, Postcommunism and the theory of democracy. Chichester; Princeton: Princeton University Press. 216 p. [in English]

Fish, M.S. Wittenberg, J. (2009). Failed democratization. C.W. Haerpfer (Ed.), Democratization. New York : Oxford University Press, 2009, P. 260-265. [in English]

Fukuyama, F. (2015). Why Is Democracy Performing So Poorly? In: L.J. Diamond, M.F. Plattner. Democracy in decline? Baltimore: Johns Hopkins University Press. [in English]

Greskovits, B. (2015). The Hollowing and Backsliding of Democracy in East Central Europe. Global Policy, № 6(1), P. 28-37. [in English]

Herman, L. (2016). Re-evaluating the post-communist success story: party elite loyalty, citizen mobilization and the erosion of Hungarian democracy. European Political Science Review, № 8(2), P. 251-284. [in English]

Huber, R.A., Schimpf, C.H. (2016). Friend or Foe? Testing the Influence of Populism on Democratic Quality in Latin America. Political Studies, № 64(4), P. 872-889. [in English]

Kapstein, E.B., Converse, N. (2008). The fate of young democracies. Cambridge University Press, Cambridge. 188 p. [in English]

Krastev, I. (2016). Liberalism’s Failure to Deliver. Journal of Democracy, № 27(1), P. 35-38. [in English]

Levitsky, S., Ziblatt, D. (2018). How Democracies Die. New York: Crown. 312 p. [in English]

Lührmann, A. et al. (2017). Democracy at Dusk? V-Dem Annual Report 2017. Gothenburg: Varieties of Democracy Institute, University of Gothenburg. 60 p. [in English]

Lust, E., Waldner, D. (2015). Theories of Democratic Change - Phase I: Theories of Democratic Backsliding. USAID Research and Innovation Grants Working Papers Series. 123 p. [in English]

Mechkova, V., Lührmann, A., Lindberg, S.I. (2017). How Much Backsliding? Journal of Democracy, № 28(4), P. 162-169. [in English]

Mounk, Y. (2018). The people vs. democracy. Why our freedom is in danger and how to save it. Harvard: U Press. 400 p. [in English]

Müller, J.-W. (2015). Should the EU Protect Democracy and the Rule of Law inside Member States. European Law Journal, № 21(2), P. 141-160. [in English]

Müller, J.-W. (2016). What is populism? Philadelphia: University of Pennsylvania Press. 136 p. [in English]

Palonen, E. (2009). Political polarisation and populism in contemporary Hungary. Parliamentary Affairs, № 62(2), P. 318-334. [in English]

Pappas, T. (2014). Populist Democracies: Post-Authoritarian Greece and Post-Communist Hungary. Government and Opposition, № 49(1), P. 1-23. [in English]

Plattner, M. F. (2017). Liberal democracy's fading allure. Journal of Democracy, № 28(4), P. 5-14. [in English]

Pop-Eleches, G. (2010). Throwing out the bums. Protest voting and unorthodox parties after communism. World Politics, № 62(2), P. 221-260. [in English]

Przeworski, A. (2005). Democracy as an Equilibrium. Public Choice, № 123(3/4), P. 253-273. [in English]

Reynolds, A. (2011). Designing democracy in a dangerous world. Oxford: Oxford University Press. 218 p. [in English] 
Runciman, D. (2018). How democracy ends. London: Profile Books. 256 p. [in English]

Rupnik, J. (2007). From Democracy Fatigue to Populist Backlash. Journal of Democracy, № 18(4), P. 17-25. [in English]

Sitter, N., Bakke, E. (2019). Democratic Backsliding in the European Union. Oxford Research Encyclopedia of Politics. [in English]

\section{Анотачія \\ Кокорєื О. В. Визначення особливостей стану ліберальної демократії як передумова оцінки ії якості в «молодих демократіях» СС. - Стаття.}

Досліджуються проблеми якості демократії в державах-учасницях $€ C$, які приєдналися в процесі останніх розширень союзу. 3'ясовуються основні прояви наростання демократичного регресу: підйом лівого та правого популізму, неліберальні урядові ініціативи, намагання влади звузити простір дії громадянського суспільства, утиски меншин (етнічних, сексуальних та ін.), наростання мови ненависті, політична корупція, демонізація біженців тощо. Діяльність ЄС у площині якості демократії охарактеризована як незадовільна, наслідком чого визначено наростання неліберальної демократії та інших видів дефектних демократій у державах-учасницях. Наявний спектр інструментів СС (зокрема й ст. 7 Договору про (С) визначено недостатнім для ефективного запобігання та протидії погіршенню якості демократії в країнах-учасницях. Підкреслено необхідність розробки та прийняття ЄС нових механізмів контролю за дотриманням демократичних стандартів у державах-учасницях. У статті приділено увагу питанню впливу інформаційно-комунікаційних технологій на ліберальну демократію (вплив онлайн-тролів та іншої віртуальної «зброї»). Доведено, що передумови для погіршення якості демократії в «молодих демократіях» Центральної та Східної Європи були закладені ще до глобальної фінансової кризи 2008 р., однак саме ця криза запустила механізми деконсолідації демократії. Виділено інституційні, політичні та економічні причини демократичного відставання держав Центральної та Східної Європи, які входять до ЄC. Зазначено, що пандемія COVID-19 не лише відклала реалізацію ЄC низки завдань щодо покращення якості демократії, а й слугувала підставою окремим державам-учасницям продовжити розширювати повноваження урядів і звужувати демократичний громадянський простір. Пандемію COVID-19 автор статті визначає як тест на стресостійкість для «молодих демократій» Центральної та Східної Європи, які входять до ЄС.

Ключові слова: автократизація, деконсолідація демократії, демократичний регрес, ліберальна демократія, популізм, якість демократії.

\section{Summary}

Kokoriev $O$. V. Defining the peculiarities of the state of liberal democracy as a prerequisite for assessing its quality in the "young democracies" of the EU. - Article.

The problems of the quality of democracy in the EU member states that joined during the recent enlargements of the union are studied. The main manifestations of the growth of democratic regress are revealed: the rise of left and right populism, illiberal government initiatives, government efforts to narrow the scope of civil society, oppression of minorities (ethnic, sexual, etc.), growing hate speech, political corruption, demonization of refugees and more. The EU's performance in the field of the quality of democracy has been described as unsatisfactory, resulting in an increase in illiberal democracy and other types of defective democracies in the member states. The current range of EU instruments (including Article 7 of the EU Treaty) is currently insufficient to effectively prevent and combat the deterioration of the quality of democracy in the member states. The need to develop and adopt new mechanisms for monitoring the observance of democratic standards in the member states was emphasized. The article focuses on the impact of information and communication technologies on liberal democracy (the impact of online trolls and other virtual "weapons"). It has been proven that the preconditions for the deterioration of the quality of democracy in the "young democracies" of Central and Eastern Europe were laid before the global financial crisis of 2008, but it was this crisis that triggered the mechanisms of democracy consolidation. The institutional, political and economic reasons for the democratic backwardness of the Central and Eastern European states that are members of the EU are highlighted. It was noted that the COVID-19 pandemic not only delayed the EU's implementation of a number of tasks to improve the quality of democracy, but also served as a basis for some member states to continue to expand the powers of governments and narrow the democratic civic space. The author of the article defines the COVID-19 pandemic as a stress test for the "young democracies" of Central and Eastern Europe, which are members of the EU.

Key words: autocratization, democratic de-consolidation, democratic regress, liberal democracy, populism, quality of democracy. 